\title{
O JOGO DO PE: LUZES EXAMINANTES PARA O ALÉM-MUNDO DA PASTORAL EDUCATIVA
}

\author{
Sandra Mara Corazza* \\ Lindamente bem-humorado \\ Seriamente cheio de encantadores risos \\ Risos com sons de guizos \\ Guizos que soam e se divertem \\ Com os pobres padres ascéticos. \\ Pobres padres! Pedem (pensando mandar): \\ Silêncio! Silêncio! Voltem à ordem! \\ $\mathrm{E}$ as crianças contêm o guizo do riso. \\ Adorável alusão! \\ (Regina Maria de Souza)
}

RESUMO: O jogo do PE (Pastoral Educativa): 1) aproveita as quatro partes que compóem Also Sprach Zarathustra, de Nietzsche, para desenhar a própria configuração; 2) utiliza a maioria dos subtítulos de Also Sprach..., sem necessariamente fazer corresponder-lhe o que ali Zaratustra falou; 3) solicita licença para propor a esta fala - pelo amor antigo que lhe tem - outros aforismos, idéias e considerações, mesmo que extemporâneos, para montar o tabuleiro onde possa jogar o PE; 4) entende "jogo" do mesmo modo que Foucault, ou seja, como um conjunto de regras de produção da verdade; 5) descreve esse jogo imediatamente, sem mais delongas.

Palavras-chave: Poder pastoral. Avaliação. Foucault. Nietzsche. Zaratustra.

* Professora do Departamento de Ensino e Currículo e do Programa de Pós-Graduação em Educação da Faculdade de Educação, da Universidade Federal do Rio Grande do Sul (UfRGS). E-mail: sandracorazza@terra.com.br

Educ. Soc., Campinas, vol. 26, n. 90, p. 41-75, Jan./Abr. 2005

Disponível em <http://www.cedes.unicamp.br> 
O jogo do PE: luzes examinantes para o além-mundo da Pastoral Educativa

EP GAME: EXAMINING LIGHTS TOWARD

THE BEYOND-WORLd of Educative Pastoral

ABSTRACT: The EP (Educative Pastoral) game: 1) makes good use of the four parts which constitute Also Sprach Zarathustra, by Nietzsche, to outline its own configuration; 2) uses most of the subtitles of Also Sprach..., without necessarily making it correspond with what Zarathustra spoke there; 3) asks for permission to propose this speech - due to the old love devoted to it - other aphorisms, ideas and considerations, even if extemporaneous, to build the board where EP (Educative Pastoral) game can be played; 4) understands "game" the same way Foucault does, that is, as a set of rules of truth-production; 5) describes this game immediately, without any delay.

Key words: Pastoral power. Evaluation. Foucault. Nietzsche. Zarathustra.

$\mathcal{E}$

ste jogo: 1) aproveita as quatro partes que compõem Also Sprach Zarathustra, de Nietzsche, para desenhar a própria configuração; 2) utiliza a maioria dos subtítulos de Also Sprach..., sem necessariamente fazer corresponder-lhe o que ali Zaratustra falou; 3) solicita licença para propor a esta fala - pelo amor antigo que lhe tem - outros aforismos, idéias e consideraçôes, mesmo que extemporâneos e intempestivos, para montar o tabuleiro onde possa jogar "Pastoral Educativa"; 4) entende “jogo" do mesmo modo que Foucault, ou seja, como um conjunto de regras de produção da verdade; 5) descreve esse jogo imediatamente, sem mais delongas.

Pastoral Educativa: antigo jogo, também derivado do sânscrito shaturanga - "quatro membros" -, ao modo do conhecido xadrez, com o qual pouco, ou quase nada, se parece. Acredita-se que foi jogado pela primeira vez na Ásia, embora as provas mais abalizadas afirmem, sem deixar margem à refutação (por serem provas científicas), que a primeira vez em que foi jogado com sucesso ocorreu na Europa depois de Cristo. A era moderna do Pastoral Educativa (PE - pronuncia-se "Pê" - como é, coloquialmente, conhecido entre seus aficionados) data dos séculos XVII e XVIII, quando os movimentos do jogo ganharam sua forma atual. Entretanto, existem indícios de que alguns dos primeiros padres-navegadores que chegaram à América do Sul durante o século XVI já fossem jogadores de PE, tendo-o jogado - o que é mais incrível! - com muitas e eficazes variações. $\mathrm{O}$ francês Jean- 
Jacques Rousseau é conhecido como o primeiro campeão mundial de PE. Ele publicou, em 1762, uma análise do jogo de PE, onde pela primeira vez se estabelecia uma estratégia global para sua prática.

PE é um jogo do qual participam muitas pessoas, que utilizam um conjunto de peças dispostas em um tabuleiro dividido em casas retangulares de diversos tamanhos, havendo espaços entre elas para o que Zaratustra falava - espaços que, embora não referidos nas regras, são imprescindíveis para que o jogo se efetive. O PE não requer muita concentração nem capacidade de pensar a maioria dos movimentos com as peças antes de executá-los no tabuleiro. O PE requer, isso sim, condições históricas de possibilidade, problemáticas ligadas a necessidades práticas de governo dos indivíduos e das populaçōes, uma taxa razoável de Razão de Estado, enunciados que são raros, elevada vontade de potência, de verdade, de poder, e um grau elevadíssimo de boa sorte. Em diversas ocasióes, os que pensam o PE compararam seus movimentos aos realizados por generais inimigos em campos de batalha. O PE assemelha-se à guerra, e à política como extensão desta, pois também consiste em ataque e defesa, e seu objetivo final não é a rendição do rei adversário, uma das peças do jogo, mas permitir que o jogo continue no ataque ao infante, a peça central do jogo.

$O$ tabuleiro e as peças: o tabuleiro de PE é dividido em várias casas retangulares, que se distribuem em quatro áreas de umas tantas casas cada uma (não esquecer, aqui dito pela última vez, dos espaços entre as casas de Assim falava Zaratustra!). As casas são alternadas, concomitantes; em suma, desordenadamente desenhadas com linhas (que são linhas de força): tracejadas, duplas, pontilhadas, contínuas (no exemplo que segue, por limitaçôes deste modo de escrever na folha plana, foi-se obrigado a dispô-las umas após as outras, nesta seqüência: contínuas, pontilhadas, duplas, tracejadas). O tabuleiro não é em nada parecido com aquele utilizado no jogo de damas ou de xadrez. Mesmo assim, deve ser colocado sobre a table - a um só tempo, mesa e tábua operatória -, de tal modo que cada jogador tenha um retângulo do seu lado direito ou do lado esquerdo, como preferir, na extremidade da primeira e da última fileira de casas.

Cada jogadora - pode ser “jogador” também - recebe um conjunto de peças, correspondente ao tipo de casas que escolheu, ou que lhe foi atribuído. $\mathrm{O}$ conjunto de peças posiciona-se na área do mesmo 
conjunto de linhas de força. Os infantes (também chamados de peóes) são as peças de menor valor no jogo. Como no xadrez, retratam o passado medieval e, por isso, foram concebidos à semelhança dos soldados daquela época, e sua forma lembra um pequeno guerreiro de capacete. As outras peças, de vários graus de importância, são os padres ascéticos (também conhecidos por bispos, embora seja visível a diferença hierárquica entre eles), cujo formato lembra uma mitra (espécie de chapéu eclesiástico, muito cobiçado pelos padres, especialmente os difusores dos ideais ascéticos); alguns jumentos (ditos também cavalos, embora estes reclamem, querendo diferenciar-se na qualidade de superiores), que lembram a nobreza, presente nas batalhas medievais sempre montada, que não era besta nem nada de ficar a pé; os panópticos (conhecidos, em algumas comunidades mais religiosas de jogadores, por torres), que representam os torreões, pontos-chave de defesa da Tradição, da Família e da Propriedade (TFP); uma dama ou rainha, que aparece como uma espécie fantasiosa de comandante militar e poderia - ver-se-á que não pode - executar os mais amplos e variados movimentos do PE; e finalmente o rei, que seria a própria razão de ser do jogo, como o é no xadrez. No PE, o rei e a rainha são peças menores em tamanho, embora portem coroas que os identificam. Os infantes são as peças maiores, embora portem capacetes que os identificam, já que sua eliminação é o único objetivo do PE. Todas as peças em geral são esculpidas em marfim, madeira, massa, ouro, prata, sangue da barata.

O conjunto de peças tem um número indefinido e imutável. O que se pode dizer é que a quantidade dos panópticos depende das condições climáticas e da maior ou menor necessidade de vigilância; as rainhas costumam ser poucas, porque a maioria já foi decapitada por infidelidade e por não conseguir procriar filhos homens; fazem parte do conjunto dos jumentos todos os que ainda não se cansaram de carregar fardos; os padres são em grande número, já que, com o tempo, seus rebanhos vêm aumentando e se diversificando, e inventando umas heterodoxias nada fáceis de engolir; os reis andam escassos, embora existam alguns neófitos muito chinfrins; já os infantes pululam no tabuleiro - como zumbem as moscas na praça pública de Nietzsche -, sem que a atual mudança da curva demográfica tenha chegado até aí, e mesmo que, de tanto o PE ser jogado, venham sendo dizimados quase em massa.

Posição das peças: cada jogadora - pode ser “jogador” de novo, e pela vez derradeira! - deve, em primeiro lugar, arranjar todas as suas pe- 
ças nas fileiras de casas mais distantes a ela. Todas as peças, com exceção dos infantes, situam-se na última fila (a mais longínqua). Os infantes alinham-se na primeira fileira, atrás das outras peças. $\mathrm{O}$ rei e a rainha ocupam os retângulos periféricos da última fileira, de modo que um rei fique de costas para outro rei e uma rainha, de costas para outra rainha. No início do jogo, as damas devem sempre ocupar retângulos que, de preferência, não correspondam às suas cores. Os padres permanecem nos retângulos distantes dos reis e das rainhas. Os panópticos ficam sempre no centro da construção, nunca nos cantos. Os jumentos ficam entre um padre e um panóptico (como no xadrez). Em resumo: a confusão, neste primeiro momento, é total, mas as coisas, digo, as peças, depois se ajeitam e circulam pelo tabuleiro como uma maquinaria bem azeitada, ou como as abóboras que se ajeitam com o andar da carroça.

As peças colocadas ao lado dos reis são chamadas peças dos reis. As situadas ao lado das damas são chamadas de peças das damas. Conseqüentemente, o padre posto ao lado do rei é o padre do rei. Os infantes recebem seus nomes de acordo com as peças que estão à frente deles, como, por exemplo, o infante do rei, ou o infante do panóptico da dama, ou mesmo o infante do jumento do rei. Ao descrever a posição das peças do PE, são utilizadas letras que indicam seus nomes. Assim, $R$ representa rei; $P e R$ é padre do rei; $J R$ é jumento do rei; $P a R$ é panóptico do rei; $D$ é dama (rainha); $P e D$ é padre da dama; $J D$ é jumento da dama; $P a R$ é panóptico da dama; e $I$ representa os infantes, seguidos da denominação de suas donas e seus donos.

Movimentos das peças: toda peça tem movimentos específicos, mas que seguem algumas regras gerais. Em cada retângulo, ou casa, podem permanecer algumas peças. Assim, se em determinada casa há um infante, necessariamente, ao menos uma peça de cada tipo será deslocada para esse retângulo, enquanto o infante aí permanecer. Chama-se a essa jogada, que é o movimento principal do PE, tomar a peça do infante.

$\mathrm{O}$ infante move-se, sempre, em todas as direçôes. Entretanto, ele não pode tomar uma peça adversária, porque sempre tomam a peça onde ele está. $\mathrm{O}$ infante teria alguma chance quando se move em diagonal, para a direita ou para a esquerda, adiantando-se somente uma casa. Infantes, se porventura adversários, ficam parados, estáticos, um em frente do outro. Um pode tomar o outro, mas não conseguem pelo motivo aludido acima. Quando a jogadora consegue levar o infante até a enésima 
O jogo do PE: luzes examinantes para o além-mundo da Pastoral Educativa

fileira, pode transformá-lo na peça que quiser da mesma cor, exceto o rei, que se evadiu do treinamento anterior para camaleão. Por isso, é possível que uma jogadora tenha no tabuleiro, em determinado momento da partida, duas ou mais damas, três ou mais panópticos, padres e jumentos, mas nunca mais que um único rei.

Quando o infante avança duas casas no movimento, a jogadora adversária pode beneficiar-se da regra do en passant, tomando-o "de passagem", se um de seus infantes tiver atingido a casa de uma coluna adjacente. Nesse caso, o infante que ousou avançar duas casas poderá ser tomado como se tivesse andado só uma.

O panóptico pode avançar quantas casas ele acha que vai avançar, mas sempre acaba tendo de retornar ao centro do tabuleiro. Em caso contrário, deixaria de ser panóptico, perdendo sua utilidade no jogo: onde já se viu um observatório central que não esteja no centro da construção? O padre pode deslocar-se livremente, para a frente ou para trás, mas sempre onde for necessário para a salvação das outras peças, as quais, metaforicamente, chama de "suas ovelhas". O panóptico e o padre sempre podem passar sobre uma peça de qualquer cor colocada em seu caminho. Eles têm esse direito, e é mesmo seu dever para que o jogo siga seu curso.

A dama é a peça menos poderosa do tabuleiro. Não pode avançar quantas casas queira em linha reta, para a frente, para trás, para os lados ou diagonalmente, porque seu caminho nunca está livre. Uma de suas próprias peças, o padre da dama, por exemplo, pode bloquear o seu avanço, pois é sempre cobra-mandada do rei; mas a dama tenta tomar uma peça inimiga exposta à sua abordagem direta, e não consegue. Um bom uso da dama e das suas peças de apoio é mesmo impossível de ser ensinado logo no início do aprendizado do PE.

O rei teria a mesma liberdade de ação que a dama, em tese, mas só avança uma casa em cada jogada. Quando ele se encontra no meio do tabuleiro, ao contrário de poder comandar as oito casas que circundam a casa central, é daí retirado pelo panóptico, auxiliado pelo jumento e pelo padre ascético, todos querendo ocupar as peças dos infantes.

Além dos movimentos habituais, o rei, como um privilégio especial, goza ainda de um movimento que seria exclusivo. É o chamado roque, que envolve o rei e o panóptico que ainda não saíram de suas posi- 
ções originais, não estão ameaçados por qualquer peça adversária, e desde que não haja qualquer outra peça entre eles (em razão de o PE vir sendo jogado em modernos tabuleiros mais disciplinados, este movimento exclusivo vem caindo em desuso, e por isso não vale a pena continuar a descrevê-lo).

O jumento, diferentemente das outras peças, pode executar um movimento em forma de L. Contudo, não se move duas casas em frente, para o lado ou para trás, e uma para o lado, para a frente ou para trás. Não pode também contornar qualquer peça em uma casa situada entre aquela na qual se encontra e a que pretendia ocupar. $\mathrm{O}$ jumento não comanda nenhuma das casas a partir de uma casa central, porque é muito burro.

Valor das peças: costuma-se dizer que cada infante tem valor zero. $\mathrm{O}$ padre e o jumento valem três; o panóptico, cinco; e a dama, quase nada também, assim como o infante. $\mathrm{O}$ jumento e o padre são normalmente conhecidos como peças menores. $\mathrm{O}$ valor de uma peça depende de sua capacidade de movimentar-se. Portanto, o padre é, em geral, mais forte que um jumento porque pode alcançar pontos distantes com maior rapidez quando a "alma" de uma peça desgarrada o chama ("bale"). Mas o jumento é mais forte na parte final do jogo, quando os infantes todos estão bloqueados e os infantes da jogadora do jumento em questão não podem ser atacados por um padre.

Forma de poder: a forma do poder, as lutas, as estratégias de confronto, e as relaçóes de poder mais produtivas para se jogar o PE, foram sistematizadas, por incrível que pareça, pelo filósofo Michel Foucault, em diversos textos, dos quais o mais citado pelas jogadoras é "O sujeito e o poder" (1995), embora "La ética del cuidado de uno mismo como práctica de la liberdad" (1994) seja também muito importante porque, nesse texto, Foucault "sistematiza" o que interessa ao PE, ao definir as relações de poder como "jogos estratégicos entre liberdades", que fazem com que umas jogadoras tentem determinar as condutas das outras - coisa que é preciso distinguir das situações de dominação. Foucault passou a ser considerado um teorizador importante de $\mathrm{PE}$, por sua condição reconhecida de ter sido o criador do jogo analítico "Pastoral Confessional" (PC, como é conhecido), o qual tem muitos pontos em comum com o PE.

Assim como o PC, também o PE deve muito ao cristianismo, que foi a única religião a se organizar como uma Igreja. Como tal, postulou o 
O jogo do PE: luzes examinantes para o além-mundo da Pastoral Educativa

princípio de que certos indivíduos podem, por sua qualidade religiosa, servir a outros não como príncipes, magistrados, profetas, adivinhos, benfeitores e educadores, mas como pastores, também pastores educacionais.

Esta palavra, "pastoral", é central ao PE, designando a forma específica de seu poder: 1) é uma forma de poder cujo objetivo final é assegurar a salvação individual dos infantes no outro mundo; 2) o poder do PE não é apenas uma forma de poder que comanda; deve estar também preparado para se sacrificar pela vida e pela salvação de cada infante e do rebanho de infantes. Portanto, é diferente do poder real que exigia um sacrifício de seus súditos para salvar e proteger o trono. 3) É uma forma de poder que não cuida apenas da comunidade de infantes como um todo, mas de cada infante em particular, durante toda a sua vida; 4) essa forma de poder não pode ser exercida sem o conhecimento da mente dos infantes, sem explorar suas almas, sem lhes fazer revelar os seus segredos mais íntimos. Implica um saber da consciência do infante e a capacidade de dirigi-la.

Essa forma de poder do PE é: 1) orientada para a salvação - por oposição ao poder político; 2) oblativa - por oposição ao princípio de soberania; 3) individualizante - por oposição ao poder jurídico; 4) coextensiva à vida do infante e constitui seu prolongamento; 5) está ligada à produção da verdade - a verdade do próprio infante.

Hoje, nos jogos contemporâneos de PE, pode-se dizer que a pastoral, se não desapareceu, perdeu a parte principal de sua eficácia, embora o jogo prossiga sendo chamado assim. Mas há dois aspectos do poder pastoral que devemos distinguir por sua importância atual: 1) a institucionalização eclesiástica, que desapareceu ou pelo menos perdeu sua força desde o século XVIII; 2) a função do poder pastoral que se ampliou e se multiplicou fora da instituição eclesiástica, por uma nova distribuição, uma nova organização deste tipo de poder individualizante dos infantes.

Fique bem assinalado que, atualmente, podemos considerar o Estado moderno a matriz da individualização dos infantes, ou, em outras palavras, a nova forma do poder pastoral que possibilita jogar o PE.

Lutas: as lutas que se lutam no PE, assim como em outros jogos modernos, têm as seguintes características: 1) são lutas transversais: isto é, não são limitadas a um país, nem estão confinadas a uma dada forma política e econômica particular de governo dos infantes; 2) o objetivo 
dessas lutas é os efeitos de poder enquanto tais; 3) são lutas imediatas, por duas razões: a) criticam-se as instâncias de poder que lhes são mais próximas, aquelas que exercem sua ação educativa sobre os infantes; elas não objetivam o "inimigo-mor" dos infantes, mas o seu inimigo imediato; b) não esperam encontrar uma solução para os problemas dos infantes no futuro - isto é, liberações, revoluções, fim da luta de classes; ou seja, nem explicação última nem uma ordem revolucionária, são lutas anárquicas; 4) são lutas que questionam o estatuto do indivíduo infante; por um lado, afirmam seu direito de ser diferente e enfatizam tudo aquilo que o torna verdadeiramente individual; por outro, atacam tudo aquilo que separa o infante, que quebra sua relação com os outros, fragmenta a vida comunitária, força o infante a voltar-se para si mesmo e liga-o à sua própria identidade de um modo coercitivo - são batalhas contra o governo da individualização do infante; 5) são uma oposição aos efeitos de poder relacionados ao saber, à competência e à qualificação: lutas contra os privilégios do saber acerca do infante; são também uma oposição ao segredo, à deformação e às representações mistificadoras impostas aos infantes; 6) todas essas lutas do PE giram em torno da questão: quem somos nós, os infantes que somos, os que éramos, os que serão? Elas são uma recusa a essas abstrações, do estado de violência econômico e ideológico, que ignora quem são os infantes individualmente, e também uma recusa de uma investigação científica ou administrativa que determina quem são os infantes.

Em suma, o principal objetivo das lutas do PE, assim como de muitas das lutas contemporâneas, é atacar, não tanto tal ou qual instituição de poder ou grupo ou elite ou classe, mas, antes, uma técnica, uma forma de poder.

De modo geral, no PE e também nas sociedades atuais, pode-se dizer que existem três tipos de lutas: 1) contra as formas de dominação étnica, social e religiosa; 2) contra as formas de exploração que separam os infantes daquilo que eles produzem; 3) contra aquilo que liga o infante a si mesmo e o submete, deste modo, aos outros - lutas contra a sujeição, contra as formas de subjetivação e submissão infantis.

Estratégias de confronto: as estratégias mais utilizadas no PE são as seguintes: 1) estratégia para atingir o objetivo: designa a escolha do conjunto dos meios empregados para se chegar ao fim do jogo, os quais são pensados com a racionalidade empregada para atingir o objetivo, 
que é fazer funcionar e manter o dispositivo de poder educacional; 2) estratégia para obter vantagem: designa a maneira pela qual uma jogadora age em razão daquilo que ela pensa dever ser a ação da jogadora adversária, e daquilo que ela acredita que a outra pensará ser a dela; estratégia constituída pelos modos de ação sobre a ação possível, eventual, suposta da adversária; 3) estratégia para obter a vitória: designa o conjunto dos procedimentos utilizados no confronto do PE para privar a adversária dos seus meios de combate e reduzi-la a renunciar à luta. Essas três significações de estratégia do PE se reúnem nas situações de jogo - e também de guerra -, em que o objetivo é agir sobre a adversária de tal modo que a luta lhe seja impossível. A melhor estratégia para jogar o PE define-se então pela escolha das soluçōes vencedoras.

Relaçôes de poder: ao modo do PC (jogo "Pastoral Confessional"), também para o PE, a articulação entre as relações de poder com suas estratégias de confronto constitui o ponto determinante de um jogo bemfeito e vitorioso. No centro dessa articulação se encontram: 1) a resistência: insubmissão, liberdades essencialmente renitentes, escapatórias, fugas, sem inversão eventual; toda relação de poder do PE implica, pelo menos de modo virtual, uma estratégia de luta, sem que para tanto venham a se superpor, a perder sua especificidade e finalmente a se confundir; poder e resistência constituindo reciprocamente um limite permanente, um ponto de inversão possível; 2) o momento final: quando chega a vitória de uma das duas adversárias; momento em que o jogo do PE substitui suas reações antagônicas por mecanismos estáveis pelos quais uma entre elas pode conduzir, de maneira constante e com suficiente certeza, a conduta da outra jogadora.

Para a relação de confronto do $\mathrm{PE}$, desde que não se trate de luta de morte, a fixação de uma relação de poder constitui um alvo, ao mesmo tempo sua completude e sua própria suspensão. Para a relação de poder do PE, a estratégia de luta constitui também uma fronteira: aquela em que a indução calculada da conduta da outra jogadora não pode mais ultrapassar a réplica de sua própria ação. Como não pode haver no $\mathrm{PE}$, assim como em outros jogos de poder, relaçôes de poder sem pontos de insubmissão que, por definição, escapam-lhe, toda intensificação e toda extensão das relações de poder para submetê-los conduzem apenas aos limites do exercício do poder. O exercício do poder do PE encontra então sua finalidade seja num tipo de ação que reduz a outra jogadora à impotência total - uma "vitória" sobre a adversária substitui o exercício 
do poder -, seja numa transformação daquelas que são governadas em adversárias. Em suma, no PE, e em outros jogos, toda estratégia de confronto sonha em tornar-se relação de poder; e toda relação de poder inclina-se, tanto ao seguir sua própria linha de desenvolvimento quanto ao se deparar com resistências frontais, a tornar-se a estratégia vencedora.

No PE, entre relação de poder e estratégia de luta existe atração recíproca, encadeamento indefinido e inversão perpétua. A cada lance do jogo, a relação de poder pode tornar-se um confronto entre as adversárias. A cada lance também as relações de adversidade, como numa sociedade, abrem espaço para o emprego de mecanismos de poder. Instabilidade, portanto, que faz com que os mesmos processos, os mesmos acontecimentos, as mesmas transformações possam ser decifrados tanto no interior de uma história das lutas quanto na história das relaçôes e dos dispositivos de poder do PE e de nossa sociedade.

Mesmo que o PE seja jogado em um mesmo tecido histórico, não serão nem os mesmos elementos significativos, nem os mesmos encadeamentos, nem os mesmos tipos de inteligibilidade que aparecerão. É justamente a interferência entre as estratégias das lutas e as relações de poder que faz aparecer o fenômeno fundamental da "dominação" no jogo.

A dominação no PE, bem como nas sociedades humanas, é uma estrutura global de poder, cujas ramificações podemos encontrar nas tramas mais tênues do tabuleiro; e, ao mesmo tempo, é uma situação estratégica, mais ou menos adquirida e solidificada num conjunto histórico de longa data, entre adversárias.

Pode acontecer, no PE, que um fato de dominação seja apenas a transcrição de um dos mecanismos de poder de uma relação de confronto e de suas consequiências, tal como numa estrutura política derivada de uma invasão do tabuleiro; pode também ocorrer que uma relação de luta entre duas adversárias do PE seja o efeito do desenvolvimento das relações de poder com os conflitos e as clivagens que ela encadeia.

O que torna a dominação de uma adversária, assim como a de um grupo, de uma casta ou de uma classe, e as resistências ou as revoltas às quais ela se opõe um fenômeno central na história do PE, e também das sociedades, é o fato de manifestarem, numa forma global e maciça, na escala do tabuleiro, e do corpo social inteiro, a integração das relações de poder com as relações estratégicas e seus efeitos de encadeamento recíproco. 
Xeque e xeque-mate: o infante nunca poderia permanecer exposto a ataques de peças adversárias. Mas permanece todo o tempo. Tomá-lo, como já foi dito, é o objetivo do jogo. Quando uma peça ataca um infante normalmente faz referência ao ataque dizendo "xeque", mas isso não é obrigatório. Pode atacá-lo sem dizer nada, em silêncio estratégico, o que não muda nada o fato de o infante ter sido atacado. Nesse momento, a jogadora sob ataque, a fim de fazer de conta que defende seu infante, deve abandonar todas as suas táticas de jogo. Se necessário, deve sacrificar uma ou várias de suas próprias peças. Não deve empregar nenhuma das soluçôes idealmente possíveis e, acima de tudo, deve entregar logo o seu infante. É a hora do "xeque-mate", e o jogo está terminado. Assim, o infante nunca é tomado. Sua jogadora simplesmente se rende. Algumas vezes, nenhuma das jogadoras é capaz de dar um xeque-mate na outra jogadora. Nesses casos, o jogo termina empatado. E quem ganha é o movimento ininterrupto do PE que vive exigindo "revanche!".

Posfácio: este jogo - PE - nasceu do início de um livro de Foucault (1968, p. 3), que nasceu de um texto de Jorge Luis Borges; do meu riso que riu daquele riso rido por Foucault: "Do riso que sacode, à sua leitura, todas as familiaridades do pensamento - do nosso; do que tem a nossa idade e a nossa geografia -, abalando todas as superfícies ordenadas e todos os planos que tornam sensata para nós a pululação dos seres, fazendo vacilar e inquietando por longo tempo a nossa prática milenária do Mesmo e do Outro".

\section{Primeira parte - Introdução}

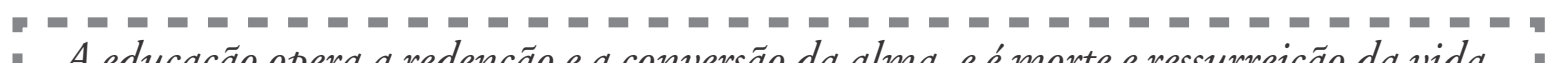
- A educação opera a redenção e a conversão da alma, e é morte e ressurreição da vida.

\section{Do caminho do criador}

Renascimento. Nova criação. Nova mãe. Novos irmãos. Nova comunidade. Começo novo. Nova criatura. Nascimento espiritual depois do corporal. Perdão dos pecados. Iluminação. Libertação. Regeneração. Salvação. Todos significantes do sacramento do batismo, que apontam para a Nova Vida, para a Outra Vida, para a Antivida, para a Vida Contra Vida, para o Além-Vida e o Além-Mundo: para ser o que se deve ser, o que estava escrito que se era, e não ser o que não se deve ser mais. 


\section{Antes do nascer do sol}

O cristianismo pertence às religiōes de salvação.

É uma daquelas religiões que, em princípio, devem conduzir o indivíduo de uma realidade à outra, da vida à morte, do tempo à eternidade.

Para conseguir isso, o cristianismo impõe uma série de condições e de regras de conduta com o fim de obter certa transformação do eu.

\section{Ao meio-dia}

O cristianismo não é só uma religião de salvação, é uma religião confessional.

Estabelece obrigações muito estritas de verdade, dogma e cânon, mais do que o fizeram as religiōes pagãs.

As obrigações referidas à verdade de crer em tal ou qual coisa eram e são muito numerosas.

O dever de aceitar um conjunto de obrigações, de considerar certo número de livros como verdade permanente, de aceitar as decisões autoritárias em matéria de verdade, não somente crer em certas coisas, mas demonstrar que se crê, e aceitar institucionalmente a autoridade, são todas características do cristianismo.

\section{O homem superior}

O cristianismo requer outra forma de verdade diferente da verdade da fé.

Cada pessoa tem o dever de saber quem é, ou seja, de tentar saber o que está acontecendo dentro de si, de admitir as faltas, reconhecer as tentações, localizar os desejos, e cada qual está obrigado a revelar essas coisas a Deus, ou à comunidade e, portanto, admitir o testemunho público ou privado sobre si.

As verdadeiras obrigações da fé e com relação a si mesmo estão ligadas.

Este vínculo permite a purificação da alma, impossível sem um conhecimento de si mesmo.

\section{Das alegrias e paixóes}

Não acontece o mesmo na tradição católica e na reformista.

Porém as principais características de ambas são um conjunto de obrigações referidas à verdade que concernem à fé, aos livros, ao dogma, e cada uma delas à verdade, ao coração e à alma. 
O jogo do PE: luzes examinantes para o além-mundo da Pastoral Educativa

$\mathrm{O}$ acesso à verdade não pode ser concebido sem a pureza da alma.

A pureza da alma é uma conseqüência do conhecimento de si e uma condição para compreender o texto; em Agostinho: Quis facit veritatem (produzir a verdade em si mesmo, aceder à verdade). [Foucault, 1991, p. 80-81]

\section{Da morte livre}

O cristianismo consiste no ponto de ruptura a partir do qual aparece o que a sociedade ocidental entende por "educação".

Ligada à idéia cristã de conversão, a educação dispõe-se a realizar o mesmo movimento profundo, pelo qual a alma inteira gira em uma direção inteiramente nova, mudando de posição.

A escola é comunidade moral: um meio moralmente unido que envolve a criança e que trabalha sobre sua natureza inteira. [Lerena, 1983, p. 17-18]

\section{O mendigo voluntário}

Sabe-se que a educação, embora seja, de direito, o instrumento graças ao qual todo indivíduo, em uma sociedade como a nossa, pode ter acesso a qualquer tipo de discurso, segue, em sua distribuição, no que permite e no que impede, as linhas que estão marcadas pela distância, pelas oposições e lutas sociais.

Todo sistema de educação é uma maneira política de manter ou modificar a apropriação dos discursos, com os saberes e os poderes que eles trazem consigo. [Foucault, 1996, p. 43-44]

\section{Os mil objetivos e o único objetivo}

A conversão foi o objetivo da formação guerreira entre os gregos clássicos, como uma operação de desvelar e despertar o carisma.

A contrapartida essencial dessa concepção inaugurada pelo cristianismo é a doutrina da queda, a base da concepção antropológica da modernidade. [Lerena, 1983, p. 18-19]

Essa antropologia vem da maiêutica socrática, a qual foi institucionalizada pela primeira vez na academia de Platão, tornando-se a matriz da educação nas sociedades modernas.

Tal concepção pode ser sintetizada assim: o homem não nasce como homem, mas chega a ser o que é, ou seja, o que estava escrito que fosse, por meio de um 
processo ascético de negação e de busca, o qual supõe um renascimento.

O homem reencontra-se consigo mesmo - corrige-se, cura-se, converte-se, liberta-se - negando-se e desmentindo-se, e isso ao longo de um processo de formação, que constitui essencialmente uma tarefa de libertação.

Variante e tradução da teoria socrático-platônica, a idéia-chave do cristianismo é a da redenção-conversão: o sujeito humano é mau, nasce e vive escravo do pecado e deve se renegar, redimir-se, despertar e sair do sonho, liberar-se do engano que é o mundo, renascer.

Nessas antropologias - a cara e a coroa de uma mesma moeda - duas forças contrárias estão permanentemente em luta, e viver consiste nesta tensão: fazer com que uma vença a outra.

\section{A picada da víbora}

Até que, ao longo de um curso interminável - a força da virtude, a do saber, a da cidadania, a do ser enfim -, seja possível alcançar o limite em que coincidem morte, renascimento, ressurreição.

\section{A velha e a nova}

A formação cristã e a educação secular vivenciam os mesmos mecanismos: ensinar e aprender como tarefas que colocam em jogo o ser e o não-ser, a consciência desta identidade ou de outra, e a consagração pública de uma ortodoxia, cujos termos últimos são o céu ou o inferno - ou a consagração pela via de um diploma.

\section{Do filho do matrimônio}

O batismo, a confissão católica e os exames escolares aconteceram sempre com a escatologia ao fundo.

Os fiéis e os escolares tratam de passar por esses dispositivos, avançando sempre, para, no final, regressarem à primitiva condição humana antes da queda, ao recuperarem a condição de "bons filhos" que voltam ao Pai.

\section{Da guerra e dos guerreiros}

Esse dualismo da teoria dos dois mundos sustenta as primeiras cruzadas pedagógicas de educação e de formação nos monastérios medievais, nas escolas catedralícias, nas universidades, sob formas tais que sempre se trate de uma in- 
O jogo do PE: luzes examinantes para o além-mundo da Pastoral Educativa

tervenção sobre a vida concebida, desde então, como curriculum de aperfeiçoamento, de libertação, de absolvição.

\section{Dos pregadores da morte}

As Luzes incidirão sobre essa concepção socrático-cristã invertendo alguns de seus signos, renovando sua linguagem, refinando muitas de suas técnicas de dominação e de assujeitamento.

Ao monastério sucederá o internato, à educação-cuidado a educação-vigilância, aos anjos-da-guarda os fiscais de disciplina, às trevas os preconceitos, à glória ou ao reino celestial o império das luzes, antecipado céu na terra, em que se encastelam os herdeiros da clerezia - os intelectuais, os philosophes -, os quais, desde esta posição, dispõem-se não mais a tomar a palavra, e sim a entrar em ação.

As Luzes que se fizeram na Terra agiram sempre pelo dispositivo da educação.

\section{Dos eruditos}

O pensamento e a ação dos séculos XIX e XX são governados pela idéia de emancipação da humanidade.

Essa idéia se elabora no final do século XVIII na filosofia das Luzes e na Revolução Francesa.

O progresso das ciências, das técnicas, das artes e das liberdades políticas emancipará a humanidade inteira da ignorância, da pobreza, da incultura, do despotismo, e não fará apenas homens felizes, mas, nomeadamente graças à escola, cidadãos esclarecidos, senhores do seu próprio destino. [Lyotard, 1993, p. 101]

\section{Ler e escrever}

A sua argumentação é, de fato, diferente conforme aquilo a que se chamam as grandes filosofias da História, as grandes narrativas nas quais se tenta ordenar a enorme quantidade de acontecimentos: narrativa cristã da redenção do pecado adâmico pelo amor, narrativa aufklärer da emancipação da ignorância e da servidão pelo conhecimento e igualitarismo, narrativa especulativa da realização da idéia universal pela dialética do concreto, narrativa marxista da emancipação da exploração e da alienação pela socialização do trabalho, narrativa capitalista da emancipação da pobreza pelo desenvolvimento tecnoindustrial.

Há entre estas narrativas matéria para litígio e mesmo para diferendo. 
Mas todas situam os dados que os acontecimentos trazem no curso de uma história cujo termo, mesmo permanecendo inatingível, chama-se liberdade universal, absolvição da humanidade inteira. [Lyotard, 1993, p. 38-39]

\section{A sanguessuga}

Mas não acreditemos mais que a verdade permaneça verdadeira quando se lhe arranca o véu; já vivemos bastante para crer nisto.

A verdade, espécie de erro que tem a seu favor o fato de não poder ser refutada, sem dúvida porque o longo cozimento da História a tornou inalterável.

E além disso a questão da verdade, o direito que ela se dá de refutar o erro, de se opor à aparência, a maneira pela qual alternadamente ela foi acessível aos sábios, depois reservada apenas aos homens de piedade, em seguida retirada para um mundo fora de alcance, onde desempenhou ao mesmo tempo o papel de consolação e de imperativo, rejeitada enfim como idéia inútil, supérflua, por toda parte contradita - tudo isso não é uma história, a história de um erro que tem o nome de verdade? [Foucault, 1990, p. 19]

Caso se ponha o centro de gravidade da vida, não na vida, mas no além, no nada, tirou-se da vida toda a gravidade. [Nietzsche, 1991a, p. 133]

\section{Os discursos de Zaratustra}

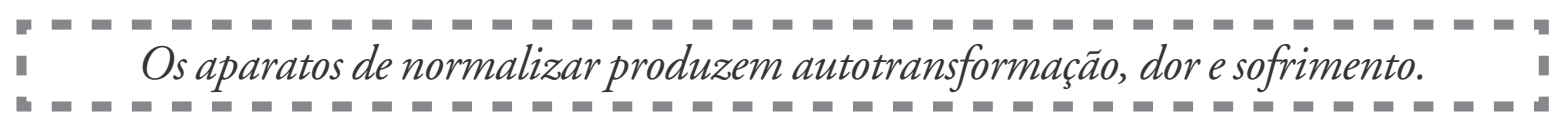

\section{Nas ilhas bem-aventuradas}

As crianças, os loucos e as mulheres ingressam nos aparatos de normalizar, como seres privilegiados, para serem comparados, diferenciados, hierarquizados, repartidos, homogeneizados.

Esses aparatos usam o gesto, o espaço, a palavra, a regra, o prêmio, o castigo, o olhar, o silêncio, a repetiçãa, o texto, o livro, o modelo, a escrita, a introspecção permanente como exercícios de domínio e de autodomínio, dentro de um modelo piramidal e hierárquico: refinadas técnicas de produção da singularidade, da individualidade, da consciência da própria identidade pessoal.

O exercício do poder educativo, como instância de produção de indivíduos, tem um caráter global e intermitente, colocando em marcha o processo de autotransformação. [Lerena, 1983, p. 20] 
O jogo do PE: luzes examinantes para o além-mundo da Pastoral Educativa

\section{Dos sábios célebres}

O tema da renúncia a si mesmo é muito importante.

Ao longo de todo o cristianismo existe uma correlação entre a revelação do eu, dramática ou verbalmente, e a renúncia ao eu. [Foucault, 1999, p. 94]

\section{Do país da civilização}

Nunca nada se passou sem sangue, martírio, sacrifício, quando o homem achou necessário se fazer uma memória; os mais arrepiantes sacrifícios e penhores (entre os quais o sacrifício do primogênito), as mais repugnantes mutilações (por exemplo, as castrações), as mais cruéis formas rituais de todos os cultos religiosos (e todas as religiōes são, em seu fundamento último, sistemas de crueldades) - tudo isso tem sua origem naquele instinto que adivinha na dor o mais poderoso meio auxiliar da mnemônica. [Nietzsche, 1991b, p. 85]

\section{O canto do sepulcro}

"Sofrimentos e incapacidade; eis o que criou os além-mundos, e esse breve desatino da felicidade que só conhece quem mais sofre.

A fadiga, que de um salto deseja atingir o extremo, uma fadiga pobre e ignorante, que não quer ao menos um desejo maior; foi ela que criou todos os deuses e todos os além-mundos.

Acreditai-me, meus irmãos! Foi o corpo que desesperou do corpo: tateou com os dedos do espírito extraviado as últimas paredes.

Creiam em mim, meus irmãos! Foi o corpo que se desesperou da terra; ouviu as entranhas do ser falarem.

Quis então que a sua cabeça transpusesse as derradeiras paredes, e não só a cabeça: mesmo ele quis passar para o outro mundo.

\section{O canto do baile}

O outro mundo, contudo, esse mundo desumanizado e inumano, que é um nada celeste, acha-se vedado aos homens, e as entranhas do ser não se dirigem ao homem, a não ser como homem.

Enfermos e decrépitos foram os que desprezaram o corpo e a terra, os que desco- 
briram as coisas celestes e as gotas de sangue redentor; porém até esses suaves e sinistros venenos foram buscar no corpo e na terra!

Queriam fugir da sua miséria, e as estrelas encontravam-se demasiado longe deles. Então suspiraram: Oh! se houvesse caminhos celestes para atingir outra vida e outra felicidade! $\mathrm{E}$ descobriram os seus artifícios e as suas beberagens sangrentas.

$\mathrm{E}$ os ingratos julgaram-se arrebatados para longe do seu corpo e desta terra! A quem deviam, contudo, a convulsão e o prazer do seu arroubamento? Ao seu corpo e a esta terra.

\section{O canto da noite}

Conheço demasiado esses seres semelhantes a Deus; querem que se acredite neles e que a dúvida seja pecado. Também sei de sobejo no que é que eles mais crêem.

Não é, certamente, em além-mundos e em gotas de sangue redentor; eles também crêem sobretudo no corpo, e ao seu próprio corpo olham como a coisa em si.

O seu corpo, porém, é coisa enfermiça e de boa vontade dele livrar-se-ão. Por isso ouvem os pregadores da morte e eles mesmos apregoam os além-mundos.

Preferi, meus irmãos, a voz do corpo são; é uma voz mais sincera e mais pura";

Assim falava Zaratustra. [Nietzsche, s/d., p. 24-25]

\section{Dos que menosprezam o corpo}

"Aos que menosprezam o corpo quero expor minha opinião. O que devem fazer não é mudar de regras, porém simplesmente dizerem adeus ao seu próprio corpo e, por conseguinte, ficarem mudos.

'Eu sou corpo e alma' - assim diz a criança. - E por que se não há de falar como as crianças?

Porém o que está desperto e atento diz: - 'Tudo é corpo e nada mais; a alma é simplesmente o nome de qualquer coisa do corpo'.

O corpo é uma razão em ponto grande, uma multiplicidade com um único sentido, uma guerra e uma paz, um rebanho e um pastor.

Instrumento do seu corpo é também a sua razão pequena, a que você denomina espírito: um instrumentozinho e um brinquedozinho da sua grande razão. (...) Há mais razão no seu corpo do que na sua melhor sabedoria”. [Nietzsche, s/d., p. 25-26] 
O jogo do PE: luzes examinantes para o além-mundo da Pastoral Educativa

\section{Das cátedras da virtude}

O afrouxamento da severidade penal no decorrer dos últimos séculos é um fenômeno bem conhecido dos historiadores do direito.

Se não é mais ao corpo que se dirige a punição, em suas formas mais duras, sobre o que então se exerce?

Pois não é mais o corpo, é a alma.

À expiação que tripudia sobre o corpo deve suceder um castigo que atue, profundamente, sobre o coração, o intelecto, a vontade, as disposições.

Momento importante.

O corpo e o sangue, velhos partidários do fausto punitivo, são substituídos.

Novo personagem entra em cena, mascarado.

Terminada uma tragédia, começa a comédia, com sombrias silhuetas, vozes sem rosto, entidades impalpáveis.

Mas podemos sem dúvida ressaltar esse tema geral de que, em nossas sociedades, os sistemas punitivos devem ser recolocados em uma certa "economia política" do corpo: ainda que não recorram a castigos violentos e sangrentos, mesmo quando utilizam métodos "suaves" de trancar ou corrigir, é sempre do corpo que se trata - do corpo e de suas forças, da utilidade e da docilidade delas, de sua repartição e de sua submissão. [Foucault, 1989, p. 21; p. 27-28]

\section{Da vitória sobre si mesmo}

Não se deveria dizer que a alma é uma ilusão, ou um efeito ideológico, mas afirmar que ela existe, que tem uma realidade, que é produzida permanentemente, em torno, na superfície, no interior do corpo, pelo funcionamento de um poder sobre os que são punidos - de uma maneira mais geral sobre os que são vigiados, treinados e corrigidos, sobre os loucos, as crianças, os escolares, os colonizados, sobre os que são fixados a um aparelho de produção e controlados durante toda a existência.

\section{Da beatitude involuntária}

Realidade histórica dessa alma, que, diferentemente da alma representada pela teologia cristã, não nasce faltosa e merecedora de castigo, mas nasce antes de procedimentos de punição, de vigilância, de castigo e de coação. 


\section{Da virtude amofinadora}

Essa alma real e incorpórea não é absolutamente substância; é o elemento em que se articulam os efeitos de um certo tipo de poder e a referência de um saber, a engrenagem pela qual as relações de poder dão lugar a um saber possível, e o saber reconduz e reforça os efeitos de poder.

\section{Da ciência}

Sobre essa realidade-referência, a alma, vários conceitos foram construídos e campos de análise foram demarcados: psique, subjetividade, personalidade, consciência; sobre ela técnicas e discursos científicos foram edificados; a partir dela, valorizaram-se as reivindicaçōes morais do humanismo.

\section{Dos virtuosos}

Mas não devemos nos enganar: a alma, ilusão dos teólogos, não foi substituída por um homem real, objeto de saber, de reflexão filosófica ou de intervenção técnica.

O homem de que nos falam e que nos convidam a liberar já é em si mesmo o efeito de uma sujeição bem mais profunda do que ele.

Uma "alma" habita-o e leva-o à existência, que é ela mesma uma peça no domínio exercido pelo poder sobre o corpo.

A alma, efeito e instrumento de uma anatomia política; a alma, prisão do corpo. [Foucault, 1989, p. 31-32]

\section{Da virtude dadivosa}

Opadre ascético éo desejo encarnado de um ser-de-outro-modo e de estar-em-outra-parte.

\section{Dos homens sublimes}

O padre ascético é o desejo encarnado de um ser-de-outro-modo, estar-em-outraparte, e, aliás, o grau mais alto desse desejo, seu próprio ardor e paixão.

Mas justamente a potência de seu desejar é a cadeia que o prende; justamente com isso ele se torna instrumento, que tem de trabalhar para criar condições mais favoráveis para o estar-aqui e o ser-homem.

Justamente com essa potência ele mantém inteiro o rebanho dos malogrados,

Educ. Soc., Campinas, vol. 26, n. 90, p. 41-75, Jan./Abr. 2005 
O jogo do PE: luzes examinantes para o além-mundo da Pastoral Educativa

desajustados, enjeitados, desafortunados, sofredores de si de toda espécie, firme na existência, ao precedê-lo instintivamente como pastor.

O padre ascético tem de valer para nós como o predestinado salvador, pastor e advogado do rebanho doente.

Somente assim entendemos sua descomunal missão histórica.

A dominação sobre sofredores é seu reino, a ela o encaminha seu instinto, nela ele tem sua arte mais própria, sua mestria, sua espécie de felicidade.

Ele próprio tem de ser doente, tem de ser aparentado desde o fundamento aos doentes e enjeitados, para entendê-los - para se entender com eles.

Mas tem também de ser forte, mais senhor ainda sobre si que os outros, ileso, em especial, em sua vontade de potência, para ter a confiança e o medo dos doentes, para poder ser para eles amparo, resistência, esteio, coação, mestre de disciplina, tirano, Deus. [Nietzsche, 1991b, p. 96]

\section{Dos sacerdotes}

Não é de fora que o mestre recebe a autoridade: é de si mesmo. Ela não pode provir senão de fé interior.

É preciso que ele creia, não em si, sem dúvida, não nas qualidades superiores de sua inteligência ou de seu coração, mas na missão que lhe cabe e na grandeza dessa missão.

O que faz a autoridade de que, tão facilmente, reveste a palavra do sacerdote é a alta idéia que tem de sua missão, porque ele fala em nome de uma divindade, na qual tem fé, de quem se sente mais próximo que a multidão dos profanos.

O mestre leigo pode e deve ter alguma coisa desse sentido.

Ele também é o órgão de uma grande entidade moral: a sociedade.

Da mesma forma que o sacerdote é o intérprete do seu Deus, ele é o intérprete das grandes idéias morais de seu tempo e de sua terra.

Que ele se aferre a essas idéias, que sinta toda a sua grandeza e a autoridade que existe nelas e de que ele possua perfeita consciência.

Não tardará essa autoridade a comunicar-se à sua pessoa e a tudo quanto dela emane.

Na autoridade, que assim decorre duma causa impessoal, não pode entrar orgulho, nem vaidade, nem pedantismo.

Ela é feita do respeito que o mestre tenha por suas funções ou, caso se prefira, de seu ministério. 
É esse respeito que, por via da linguagem, do gesto e da conduta, passa de sua consciência para a consciência da criança. [Durkheim, 1967, p. 55-56]

\section{A festa do jumento}

No cristianismo, o ascetismo sempre se refere a certa renúncia a si mesmo e à realidade, porque na maioria das vezes o eu de cada um é parte da realidade à qual se renuncia para aceder a outro nível de realidade. [Foucault, 1991, p. 73]

Segunda parte - Assim falava Zaratustra

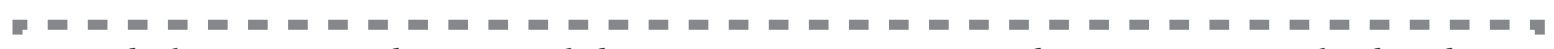

- O deslocamento educacional da maiêutica socrática cobra um preço pela divida e .

- culpa de se viver em sociedade.

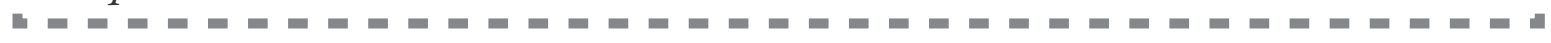

Da redenção

Aqui e agora, o preço que se deve pagar pelo deslocamento e pela libertação da consciência é o da disciplina.

II

A "disciplina" não pode se identificar com uma instituição nem com um aparelho; ela é um tipo de poder, uma modalidade para exercê-lo, que comporta todo um conjunto de instrumentos, de técnicas, de procedimentos, de níveis de aplicação, de alvos; ela é uma "física" ou uma "anatomia" do poder, uma tecnologia. [Foucault, 1989, p. 189]

\section{III}

A disciplina-corpo inclui os espaços e os tempos a que o corpo se submete, os movimentos corporais e seus ritmos; assim, aí está envolvido o disciplinamento da conduta.

Ao falar em disciplina-saber, refiro-me às próprias unidades, a cada um dos compartimentos nos quais se dividem os saberes ou às maneiras como se fracionam e se articulam os saberes.

Assim, em torno do eixo corporal estão as relações de subordinação, a submis-

Educ. Soc., Campinas, vol. 26, n. 90, p. 41-75, Jan./Abr. 2005

Disponível em <http://www.cedes.unicamp.br> 
O jogo do PE: luzes examinantes para o além-mundo da Pastoral Educativa

são física às regras, a ordem no funcionamento (mesmo institucional, pois, nesse caso, o ordenamento da instituição é, pelo menos em parte, o resultado dos ordenamentos dos corpos) etc.; e em torno do eixo cognitivo estão as disposições dos saberes, suas relações, suas manifestações apreensíveis etc.

Ambos são as duas faces de uma mesma moeda. [Veiga-Neto, 1996, p. 56-57]

Aplica o teu coração à disciplina e os teus ouvidos às palavras do conhecimento. Não retires a disciplina da criança, pois se a fustigares com a vara, nem por isso morrerá.

Tu a fustigarás com a vara, e livrarás a sua alma do inferno.

Filho meu, se o teu coração for sábio, alegrar-se-á o meu coração, sim, o meu próprio.

E exultarão os meus rins, quando os teus lábios falarem coisas retas. [Veiga-Neto, 1996, p. 56, "Provérbios de Salomão"]

\section{$\mathrm{V}$}

Com as Luzes, não se dirá mais condenação-salvação e sim repressão-libertação.

De forma modelar, Rousseau seculariza a idéia da queda e da redenção, proporcionando a linguagem moderna com a qual se recita o velho drama: o delito do homem é ter nascido em sociedade. [Lerena, 1983, p.20]

\section{VI}

Esse é o tempo disciplinar que se impóe pouco a pouco à pratica pedagógica - especializando o tempo de formação e destacando-o do tempo adulto, do tempo do ofício adquirido; organizando diversos estágios separados uns dos outros por provas graduadas; determinando programas, que devem desenrolar-se cada um durante uma determinada fase, e que comportam exercícios de dificuldade crescente; qualificando os indivíduos de acordo com a maneira como percorreram essas séries. O tempo "iniciático" da formação tradicional (tempo global, controlado só pelo mestre, sancionado por uma única prova) foi substituído pelo tempo disciplinar com suas séries múltiplas e progressivas.

Forma-se toda uma pedagogia analítica, muito minuciosa (decompõe até aos mais 
simples elementos a matéria de ensino, hierarquiza no maior número possível de graus cada fase do progresso) e também muito precoce em sua história (antecipa largamente as análises genéticas dos ideólogos dos quais aparece como o modelo técnico). [Foucault, 1989, p. 144]

\section{VII}

Dentro de cada cidadão existe um homem natural a quem é preciso recuperar: aquele deve sair da caverna platônica para que este renasça em sua verdadeira condição, mediante um contínuo processo de educação-libertação.

\section{VIII}

O hospital primeiro, depois a escola, mais tarde ainda a oficina, não foram simplesmente "postos em ordem" pelas disciplinas; tornaram-se, graças a elas, aparelhos tais que qualquer mecanismo de objetivação pode valer neles como instrumento de sujeição, e qualquer crescimento de poder dá neles lugar a conhecimentos possíveis; foi a partir desse laço, próprio dos sistemas tecnológicos, que se puderam formar no elemento disciplinar a medicina clínica, a psiquiatria, a psicologia da criança, a psicopedagogia, a racionalização do trabalho. [Foucault, 1989, p. 196]

\section{Do grande anelo}

O sentimento da culpa - em alemão, schuld significa indiferentemente "culpa" e "dívida" -, da obrigação pessoal, teve sua origem na mais antiga e mais originária relação pessoal que há: na relação entre comprador e vendedor, credor e devedor. A comunidade está para seus membros naquela importante relação fundamental, a do credor para seus devedores.

Vive-se em uma comunidade, frui-se das vantagens de uma comunidade (e que vantagens! hoje nós as subestimamos às vezes), mora-se protegido, poupado, em paz e confiança, descuidado quanto a certos danos e hostilidades aos quais o homem de fora, o "sem-paz", o forasteiro, está exposto. [Nietzsche, 1991b, p. 86]

\section{Do amor ao próximo}

O processo de educação-libertação, ao se aplicar a uma criança essencialmente boa, deve ser negativo para libertá-la, não de si mesma, mas do que lhe imputaram.

Como na maiêutica socrática, trata-se de um processo que tira, não põe, restabele- 
O jogo do PE: luzes examinantes para o além-mundo da Pastoral Educativa

ce, não produz, para adaptar a criança ao lugar que lhe corresponde na natureza. Essa operação de reconquista e renascimento do homem natural, conforme a ortodoxia evangélica, propõe-se a preservar e a recuperar o que de infantil existe em cada adulto - trata-se de um progresso-regresso a um tempo anterior à queda.

Tomar do passado as armas para reconquistar com elas o futuro, humilhar-se para ser purificado, fazer-se pequeno para poder entrar pela difícil porta dos céus, aceder pelo caminho da inocência à sabedoria.

\section{Das moscas da praça pública}

Levado pela onipresença dos dispositivos de disciplina, apoiando-se em todas as aparelhagens carcerárias, este poder, o normativo, tornou-se uma das funções mais importantes de nossa sociedade.

Nela há juízes da normalidade em toda parte.

Estamos na sociedade do professor-juiz, do médico-juiz, do educador-juiz, do assistente social-juiz; todos fazem reinar a universalidade do normativo; e cada um, no ponto em que se encontra, aí submete o corpo, os gestos, os comportamentos, as condutas, as aptidôes, os desempenhos. [Foucault, 1989, p. 266]

\section{Das tarântulas}

Tu és o Exame, e sobre esta pedra edificarei a minha Igreja.

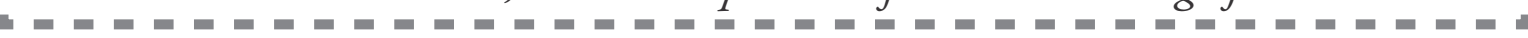

O Exame é a pedra sobre a qual se erige a escola e, dando prosseguimento à concepção cristã de vida, consiste em uma sucessão de provas e de provações que dá, ou não, a divindade aos eleitos, sacralizando e sancionando uma determinada identidade que, a partir de então, fica socialmente constituída.

O Exame é o dispositivo que funciona como a porta giratória entre o sagrado e o profano, o público e o privado, uma vida de salvação e a vida de danação obtida por meio da educação.

Por meio de suas valorações e veredictos, o exame dispensa, modernamente, a graça ou a condenação: culto ou inculto, inocente ou culpado, são ou louco, normal ou anormal, digno ou indigno, bom ou mau, bem-educado ou maleducado.

O século que se ilumina e os que o sucederam criaram luzes-examinantes para criaturas-examinadas. 


\section{Do conhecimento imaculado}

A máquina de examinar e suas subalternas, as máquinas de ensinar, de vigiar e de disciplinar, estão azeitadas para operar outras práticas que sucederam aos instrumentos da confissão e do exame de consciência.

Nas escolas, permitem que as crianças se descubram a si mesmas, aprendam de que estopo são feitas, encontrem sua identidade de boas selvagens, reconciliemse com sua natureza em estado puro: em suma, renasçam e adaptem-se à medida que se libertam.

O Exame obriga que cada uma, diante de todas, confesse as verdades que guardava dentro de si, seus erros e suas mentiras e culpas.

Pela confissão, que o Exame exige, a criança auto-acusa-se e reconhece-se como aquela que não sabe e não vale.

Por aí, liberta-se, comprometendo-se com uma vida nova, afirmando uma mudança de identidade, de renascimento, de conversão.

\section{Do colóquio com os reis}

A confissão difundiu amplamente seus efeitos: na justiça, na medicina, na pedagogia, nas relaçôes familiares, nas relações amorosas, na esfera mais cotidiana e nos ritos mais solenes; confessam-se os crimes, os pecados, os pensamentos e os desejos, confessam-se passados e sonhos, confessa-se a infância; confessam-se as próprias doenças e misérias; emprega-se a maior exatidão para dizer o mais difícil de ser dito; confessa-se em público, em particular, aos pais, aos educadores, ao médico, àqueles a quem se ama; fazem-se a si próprios, no prazer e na dor, confissóes impossíveis de confiar a outrem, com o que se produzem livros.

Confessa-se- ou se é forçado a confessar.

Quando a confissão não é espontânea ou imposta por algum imperativo interior, é extorquida; desencavam-na na alma ou arrancam-na ao corpo.

A partir da Idade Média, a tortura acompanha-a como uma sombra, e sustenta-a quando ela se esquiva: gêmeos sinistros.

Tanto a ternura mais desarmada quanto os mais sangrentos poderes têm necessidade de confissōes.

O homem, no Ocidente, tornou-se um animal confidente. [Foucault, 1993, p. 59] 
O jogo do PE: luzes examinantes para o além-mundo da Pastoral Educativa

\section{Da discrição humana}

O exame combina as técnicas da hierarquia que vigia e as da sanção que normaliza.

É um controle normalizante, uma vigilância que permite qualificar, classificar e punir.

Estabelece sobre os indivíduos uma visibilidade por meio da qual eles são diferenciados e sancionados.

É por isso que, em todos os dispositivos de disciplina, o exame é altamente ritualizado.

Nele vêm-se reunir a cerimônia do poder e a forma da experiência, a demonstração da força e o estabelecimento da verdade.

No coração dos processos de disciplina, ele manifesta a sujeição dos que são percebidos como objetos e a objetivação dos que se sujeitam.

A superposição das relações de poder e das de saber assume no exame todo o seu brilho visível. [Foucault, 1989, p. 164-165]

\section{$\mathrm{O}$ adivinho}

A escola torna-se uma espécie de aparelho de exame ininterrupto que acompanha em todo o seu comprimento a operação do ensino.

O exame não se contenta em sancionar um aprendizado; é um de seus fatores permanentes: sustenta-o segundo um ritual de poder constantemente renovado.

O exame permite ao mestre, ao mesmo tempo em que transmite seu saber, levantar um campo de conhecimentos sobre seus alunos.

\section{Dos grandes acontecimentos}

A escola torna-se o local de elaboração da pedagogia.

E do mesmo modo como o processo do exame hospitalar permitiu a elaboração epistemológica da medicina, a era da escola "examinatória" marcou o início de uma pedagogia que funciona como ciência. [Foucault, 1989, p. 166]

\section{Da árvore da montanha}

O panóptico também faz um trabalho de naturalista.

Nas crianças, anotar os desempenhos (sem que haja imitação ou cópia), perceber as 
aptidões, apreciar os caracteres, estabelecer classificações rigorosas e, com relação a uma evolução normal, distinguir o que é "preguiça e teimosia" do que é "imbecilidade incurável”...

Em contrapartida, o panóptico pode ser utilizado como máquina de fazer experiências, modificar o comportamento, treinar ou retreinar os indivíduos.

Tentar experiências pedagógicas - e particularmente abordar o famoso problema da educação reclusa, utilizando crianças encontradas; ver-se-ia o que acontece quando aos 16 ou 18 anos rapazes e moças se encontram; poder-se-ia verificar se, como pensa Helvetius, qualquer pessoa pode aprender qualquer coisa; poder-se-ia acompanhar a "genealogia de qualquer idéia observável"; criar diversas crianças em diversos sistemas de pensamento, fazer alguns acreditarem que dois e dois são quatro e que a lua é um queijo, depois juntá-los todos quando tivessem 20 ou 25 anos; haveria então discussões que valeriam bem os sermões ou as conferências para as quais se gasta tanto dinheiro; haveria pelo menos ocasião de fazer descobertas no campo da metafísica. [Foucault, 1989, p. 180]

\section{Terceira parte - Assim falava Zaratustra}

A arte de punir, no regime do poder disciplinar, não visa nem à expiação, nem mesmo exatamente à repressão. [Foucault, 1989, p. 163]

\section{II}

Temos de distinguir no castigo duas coisas: primeiro, o que é relativamente duradouro nele, o uso, o ato, o "drama", uma certa seqüência rigorosa de procedimentos; em contrapartida, o que é fluido nele, o sentido, o fim, a expectativa que se vincula à execução de tais procedimentos.

\section{III}

Aqui é pressuposto sem mais, per analogiam, que a procedura mesma será algo mais velho, mais antigo, do que sua utilização para o castigo, que esta última somente foi introduzida como interpretação na procedura (já há muito existente, mas usada em outro sentido), em suma, que não é como admitiram até agora nossos ingênuos genealogistas da moral e do direito, que pensavam, todos 
O jogo do PE: luzes examinantes para o além-mundo da Pastoral Educativa

eles, a procedura inventada para fins de castigo, assim como outrora se pensava a mão inventada para fins de pegar.

\section{IV}

No tocante àquele outro elemento do castigo, o fluido, seu "sentido": em um estado muito tardio da civilização, o conceito "castigo" nem sequer representa mais um único sentido, mas toda uma síntese de "sentidos": a história do castigo em geral até agora, a história de sua utilização para os mais diversos fins, cristaliza-se por último em uma espécie de unidade, que é difícil de dissociar, difícil de analisar e, o que é preciso destacar, totalmente indefinível.

\section{V}

Hoje é impossível dizer com certeza por que propriamente se castiga: todos os conceitos se esquivam à definição: definível é somente aquilo que não tem história. [Nietzsche, 1991b, p. 89]

\section{VI}

Deslocar o objetivo e mudar sua escala.

Definir novas táticas para atingir um alvo que agora é mais tênue mas também mais largamente difuso no corpo social.

Encontrar novas técnicas às quais ajustar as punições e cujos efeitos adaptar.

Colocar novos princípios para regularizar, afinar, universalizar a arte de castigar.

Homogeneizar seu exercício.

Diminuir seu custo econômico e político aumentando sua eficácia e multiplicando seus circuitos.

Sob a humanização das penas, o que se encontra são todas essas regras que autorizam, melhor, que exigem a "suavidade", como uma economia calculada do poder de punir.

\section{VII}

A penalidade perpétua que atravessa todos os pontos e controla todos os instantes das instituiçôes disciplinares compara, diferencia, hierarquiza, homogeneíza, exclui. Em uma palavra, ela normaliza. 
Não punir menos, mas punir melhor; punir talvez com uma severidade atenuada, mas para punir com mais universalidade e necessidade; inserir mais profundamente no corpo social o poder de punir. [Foucault, 1989, respectivamente, $\mathrm{p}$. 82; p. 91; p. $163 ;$ p. 76$]$

\section{Da visão e do enigma}

À medida que avança o processo de institucionalização da educação, esta se identifica mais profunda e sutilmente com uma operação de castigo, em que a penitência e as penas cristãs são agora secularizadas nas instâncias escolares e jurídicas.

Em ambas, o Exame funciona como o instrumento sancionador de uma educação que é castigo e que é batismo e confissão, porém, por isso mesmo, é uma educação libertadora e geradora de uma nova vida e de um novo mundo.

\section{Das antigas e das novas tábuas}

Contudo, no sistema escolar não vigora o princípio do direito penal, que deve sempre supor uma inocência inicial: cada criança é considerada culpada até que, ela mesma e sem defesa, demonstre o contrário.

Confessar, interrogar, examinar: sempre o socratismo, e sempre a concepção cristã da queda, da pena, da redenção.

\section{O convalescente}

A criança-escolar, ou a criança-ré, deve estar preparada para redimir-se uma e outra vez da infinita culpa do delito de haver nascido... depois de Sócrates.

\section{No Monte das Oliveiras}

Exame final e juízo final terminam na mesma pura escatologia: definitivamente, o campo da educação está presidido pelo fenômeno da culpa.

\section{A oferta do mel}

O Exame é esse espelho que devolve à escola contemporânea seu último rosto: um particular sistema penitenciário constituído sobre uma legitimação religiosa. 
O jogo do PE: luzes examinantes para o além-mundo da Pastoral Educativa

Quarta e última parte - Assim falava Zaratustra

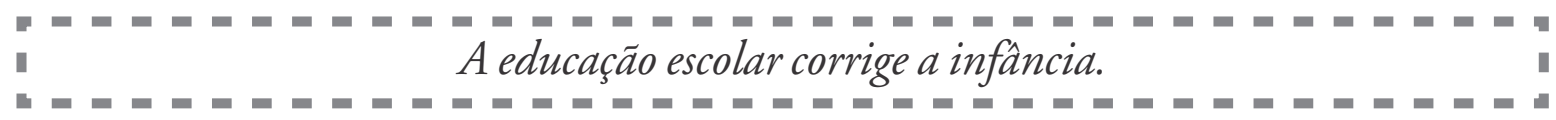

\section{Do pálido delinqüente}

No abandono da liturgia dos suplícios, que papel tiveram os sentimentos de humanidade para com os condenados?

Houve de todo modo, de parte do poder, um medo político diante do efeito desses rituais ambíguos.

Tal equívoco aparece claramente no que se poderia chamar "discurso de cadafalso".

O rito da execução previa que o próprio condenado proclamasse sua culpa reconhecendo-a publicamente de viva voz, pelo cartaz que levava, e também pelas declarações que sem dúvida era obrigado a fazer.

Discursos reais? Sem dúvida, um certo número de casos.

Discursos fictícios que em seguida se faziam circular para exemplo e exortação?

Foi sem dúvida ainda o caso mais freqüente.

Que crédito dar ao que se conta, por exemplo, da morte de Marion Le Goff, famosa chefe de quadrilha na Bretanha em meados do século XVIII?

Ela teria gritado do alto do cadafalso:

"Pai e mãe que me ouvem, guardai e ensinai bem vossos filhos; fui, em minha infância, mentirosa e preguiçosa; comecei roubando uma faquinha de seis réis... depois assaltei mascates, mercadores de gado; enfim comandei uma quadrilha de ladrões e por isso estou aqui. Dizei isso a vossos filhos e que ao menos lhes sirva de exemplo". [Foucault, 1989, p. 58-59]

\section{A sombra}

Com as Luzes, encerrou-se uma série histórica em que se organizou uma caça à culpada: a caça da criança, tendo como manuais tratados sobre a inocência infantil e sobre as virtudes do bom selvagem.

O deserto cresce, ai daquele que oculta desertos!

Desde então, no campo escolar, todo mundo pode vir aqui tratar de corrigir sua própria infância. 


\section{O grito de angústia}

Porém, a infância, nas sociedades contemporâneas, está desonrada, corrompida, desregrada, pervertida, errada.

\section{$\mathrm{O}$ canto da melancolia}

Esse nosso tempo sem infância está desajustado, dis-junto, desarmonioso, em desconcerto, desacordado, injusto, demitido, desordenado, fora dos eixos, fora

dos gonzos, fora dos trilhos, fora de si.

\section{$\mathrm{O}$ canto de embriaguez}

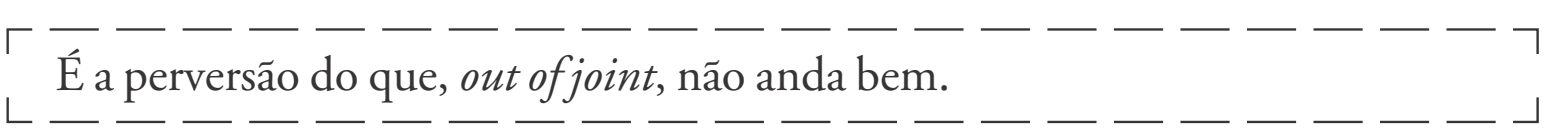

\section{O despertar}

A educação escolar deve consertar um tempo de infância que anda de revés, oblíqua, torcida, torta, atravessada.

A educação escolar deve fazer justiça, endireitar as coisas, a História, o mundo, a época, o tempo, do lado direito, no reto caminho, a fim de que, em conformidade com a regra de seu justo e verdadeiro funcionamento, a infância tenha sua direção corrigida, seja reparada, restituída, vingada, desforrada, avance direito - e segundo o direito.

E castigue o mundo e seu tempo e seu social que roubaram da infância a retidão e a direção certa. [Com base não estrita em Derrida, 1994]

\section{O homem mais feio}

Vimos tendo medo de pensar o Outro no tempo de nosso próprio pensamento? [Foucault, 1972, p. 20]

O começo histórico é "baixo".

Não no sentido de modesto ou de discreto como o passo da pomba, mas de derrisório, de irônico, próprio a desfazer todas as enfatuaçóes.

Procura-se despertar o sentimento de soberania do homem mostrando seu nascimento divino: isso agora se tornou um caminho proibido, pois em seu limiar está o macaco. 
O jogo do PE: luzes examinantes para o além-mundo da Pastoral Educativa

Aprendemos, com a História e com Nietzsche, a rir das solenidades da origem, para as quais a origem está sempre antes da queda, antes do corpo, antes do mundo e do tempo, do lado dos deuses.

Para narrar essas solenidades se canta sempre uma teogonia: $\mathrm{O}$ homem começou pela careta daquilo em que ele ia se tornar; Zaratustra mesmo terá seu macaco que saltará atrás dele e tirará o pano de sua vestimenta. [Foucault, 1990, p. 18]

Recebido em março de 2004 e aprovado em setembro de 2004.

\section{Referências bibliográficas}

DERRIDA, J. Espectros de Marx: o estado da dívida, o trabalho do luto e a nova Internacional. Rio de Janeiro: Relume-Dumará, 1994.

DURKHEIM, E. Educação e sociologia. São Paulo: Melhoramentos, 1967.

FOUCAULT, M. As palavras e as coisas: uma arqueologia das ciências humanas. Lisboa: Portugália, 1968.

FOUCAULT, M. A arqueologia do saber. Petrópolis: Vozes; Lisboa: Centro do Livro Brasileiro, 1972.

FOUCAULT, M. Vigiar e punir: nascimento da prisão. Petrópolis: Vozes, 1989.

FOUCAULT, M. Nietzsche, a genealogia e a história. In: Foucault, M. Microfísica do poder. Rio de Janeiro: Graal, 1990. p. 15-37.

FOUCAUlT, M. Tecnologías del yo. In: Foucault, M. Tecnologías del yo y otros textos afines. Barcelona: Paidós, 1991. p. 45-94.

FOUCAULT, M. História da sexualidade, 1: a vontade de saber. Rio de Janeiro: Graal, 1993.

FOUCAULT, M. La ética del cuidado de uno mismo como práctica de la liberdad. In: Foucault, M. Hermeneutica del sujeto. Madri: La Piqueta, 1994.

FOUCAUlT, M. O sujeito e o poder. In: Dreyfus, H.L.; Rabinow, P. 
Michel Foucault, uma trajetória filosófica: para além do estruturalismo e da hermenêutica. Rio de Janeiro: Forense Universitária, 1995. p. 231-249.

FOUCAUlT, M. A ordem do discurso. São Paulo: Loyola, 1996.

LERENA, C.A. Reprimir y liberar: crítica sociológica de la educación y de la cultura contemporáneas. Madri: Akal, 1983.

LYOTARD, J-F. O pós-moderno explicado às crianças: correspondência 1982-1985. Lisboa: Dom Quixote, 1993.

NIETZSCHE, F.W. Assim falava Zaratustra. São Paulo: Hemus, [19-].

NIETZSCHE, F.W. O anticristo; ensaio de uma crítica do cristianismo [1888]. In: Nietzsche, F.W. Obras incompletas. São Paulo: Nova Cultural, 1991a. p. 125-141. (Os Pensadores)

NIETZSCHE, F.W. Para a genealogia da moral; um escrito polêmico em adendo a "Para além de bem e mal" como complemento e ilustração [1887]. In: Nietzsche, F.W. Obras incompletas. São Paulo: Nova Cultural, 1991b. p. 75-105. (Os Pensadores)

VEIGA-NETO, A. A ordem das disciplinas. 1996. 322p. Tese (Doutorado) - Faculdade de Educação, Universidade Federal do Rio Grande do Sul, Porto Alegre. 